\title{
LOGISTIC PERFORMANCE INDEX OF OECD MEMBERS ${ }^{1}$
}

\author{
$* * *$ \\ OECD ÜYELERININ LOJISTIK PERFORMANS İNDEKSI
}

\author{
Dr. Öğr. Üyesi Abdulkadir ATALAN \\ Gaziantep İslam Bilim ve Teknoloji Üniversitesi \\ Mühendislik ve Doğa Bilimleri Fakültesi \\ Endüstri Mühendisliği Bölümü \\ abdulkadiratalan@gmail.com \\ ORCID: 0000-0003-0924-3685
}

\begin{abstract}
Logistics Performance Index (LPI) values of the countries are considered in order to show the development levels of the countries' logistics infrastructure. In this study, the LPI values of the next period were calculated by evaluating the current LPI values of OECD members. The estimation series method was developed by using nonlinear equations for this study. The estimation data differed according to the degree of reliability of the equations. Estimated LPI data ranged from 2.869 to 4.206, with an average value of 3.611 based on equations. According to the developed method of the study, the maximum value of LPI was estimated for Sweden. In contrast, the lowest value of LPI was determined for Slovenia among the members of OECD. In brief, a significant decrease in the estimated LPI values was observed in the majority of OECD members.
\end{abstract}

Keywords: Logistics Performance Index, OECD Members, Estimation Series, Degree of Reliability.

\section{$\ddot{O} z$}

Ülkelerin lojistik altyapılarının gelişmişlik düzeylerini göstermek için ülkelere ait Lojistik Performans İndeks (LPI) değerleri dikkate alınmaktadır. Bu çalışmada OECD üyelerinin mevcut LPİ değerleri göz önünde bulundurularak bir sonraki döneme ait LPI değerleri hesaplanmıştır. Bu çalı̧̧ma için geliştirilen yöntem ile doğrusal olmayan denklemler kullanılarak tahmin serisi metodu geliştirilmiştir. Tahmin verileri, denklemlerin güvenilirlik derecesine göre farklllik göstermiştir. Tahmini LPI verileri 2,869 ile 4,206 arasında yer almıştır ve ortalama değer 3.611 olarak hesaplanmuştır. İsveç maksimum LPI değerine sahip olurken Slovenya'nın en düşük LPI değerine sahip olduğu tespit edilmiştir. Sonuç olarak, tahmini LPI değerlerinde OECD üyelerinin büyük bir kısminda düşüş olduğu gözlemlenmiştir.

Anahtar Kelimeler: Lojistik Performans Indeksi, OECD üyeleri, Tahmin Serisi, Güvenirlilik Derecesi.

\footnotetext{
${ }^{1}$ This work was presented by author at the $3^{\text {rd }}$ International Conference on Advanced Engineering Technologies (ICADET) that was organized by Bayburt University 19-21 September 2019.
} 


\section{INTRODUCTION}

Logistics has nowadays become one of the most crucial human needs (Chapman et al., 2003; Davidson, 2006). The former perception of logistics was simply based on the supply chain management, whose purpose was providing the delivery of all needed items for the manufacturing in an appropriate manner. Yet, with the modernization and globalization of the market, this term also gained different dimensions, such as the connection between time and location (Puertas et al., 2014). The logistics industry's current definition is considered a whole for functionality, transportation, communication, delivery, circulation, and storage operations (Lan et al., 2017). Reaching a product with technological advances is now a click away for customers. The most crucial role of a product from the manufacturer to the supplier and from the supplier to the customer belongs to the logistics companies.

The Logistics Performance Index, formed by the World Bank biennially as a performance test of countries concerning their logistics supply chain qualification, is an essential criterion according to a global statistical study associated with carrying agents and express transporters operating internationally. LPI may contribute to determining aspects to overcome, and potentials countries have so as to enhance their logistics performance in turn by enabling to compare 167 countries.

Logistic performance changes countries economically and structurally due to the multiple indications that logistic performance indices are affected (Devkota et al., 2013; Hollweg ve Wong, 2009). LPI is a value and a demonstration of the development of countries' trade infrastructure, such as customs procedures, logistics costs, land, sea, and air transport (Martí et al., 2014). LPI should not only be connected to the infrastructure of countries but should be considered as sustainability in the economy, flexibility in transportation, and growth in trade volume, providing the most important contributions to countries. The logistics industry's main reasons play an essential role in terms of sustainability are the active use of human resources, products, transportation vehicles, and warehouses (Lan ve Zhong, 2018).

The significance of the logistics sector for countries in terms of economic importance have been widely discussed by the researchers (Arvis et al., 2018; Childerley, 1980; Karmarkar ve Apte, 2007; Kovács ve Kot, 2016; Tseng et al., 2005). The essential issue in the studies has been the relationship between the transportation infrastructure and the economic growth of the countries (Atalan, 2019). The studies emphasized that the influence of logistics infrastructure in determining economic growth was low. Conversely, the researchers warned that the logistics sector's impact on the development of the country's economy should be considered long-term. Another study highlighted that the globalization of the economy and the logistics sector contributed greatly to national and regional economic growth (Lan et al., 2017). The fact that the logistics industry is related to economic growth stems from the coordination of both terms (Lan ve Zhong, 2018). Besides having a crucial effect on the economic dimension of the countries, the logistics industry plays an important role in the international trade relations, too (Martí et al., 2014).

In this study, an estimation index for the future was formed by considering the OECD countries' current and previous logistic indexes. The main elements of the OECD formation with 35 members to calculate the logistic performance index are transportation, education, procurement, and health issues countries have (The World Bank, 2018). For this work, the logistic performance of OECD members was taken into consideration. The World Bank has created the index since 2007 by calculating the logistic performance of the countries (Rezaei et al., 2018). The World Bank has developed such a method to demonstrate how efficiently the supply chain firms contribute to the national economies (Atalan, 2018). LPI value is evaluated as 1 for the lower limit and 5 for the upper limit (The World Bank, 2018). It is thought that the logistic performance levels of the countries advance as they approach 5 and have a weak performance as they approach 1 . In this study, an estimation process was performed by taking these data ranges into account.

Many factors are affecting the LPI, only six of which The World Bank has considered that are customs, infrastructure, international shipments, logistic quality and competence, tracking and tracing, and timelines (J. F. Arvis et al., 2010, 2012, 2014, 2018; Jean-Francois Arvis et al., 2007; Jean-François Arvis et al., 2016). No indicators but only the constructed values of LPI by the World Bank were regarded to calculate the estimated values of LPI for this study. The focus was first on demonstrating the distribution of the data, defined as how widespread the data was, and then construct equations based 
on each OECD member's degrees of reliability (Atalan, 2020; Atalan et al., 2020). The primary purpose was to estimate the values of LPI for the next time, not for the next year, because of the discontinuity of the World Bank data.

This research consists of four main parts. Information about the literature of the study was given in the introduction part of the study. The estimation equations developed for the research and the data derived from the equations were occupied in the study's methodology. The interpretation of the data was included, and the average and estimated LPI values were comparatively given in the results section. In the last part of the study, the conclusion was shared with the readers. Consequently, this research argued that it is important to pay attention with respect to the calculation of LPI and determine future LPI levels of OECD members as a useful tool for benchmarking in the logistics industry.

\section{METHODOLOGY}

LPI data of OECD countries used in this study covering the years of 2007-2018 were constructed by the World Bank (J. F. Arvis et al., 2010, 2012, 2014, 2018; Jean-Francois Arvis et al., 2007; Jean-François Arvis et al., 2016). Nevertheless, there was no continuity in the data between these years. World Bank data has been shared online for the years of 2007, 2010, 2012, 2014, 2016, and 2018. The values of LPI range from 1 to 5 . The World Bank has considered multiple factors for the calculation of the LPI. However, in this study, no addition or subtraction was performed for these factors. Only the values of LPI themselves were considered within the scope of this research.

The dispersion of the 6-year (A total of 288 data were used for each year, and the total number of observed data is 1728.) The LPI data of OECD members were depicted in Figure 1. The data was rearranged as a descending order based on the values of LPI. The distribution of LPI data was determined by the data-analyzer tool, which was appropriate to the Johnson Transformation distribution. The data points followed a straight line, and the p-value of the data was determined as 0.328 , which was greater than 0.05 . Germany had the maximum value of LPI (4.135), and the lowest value of LPI was observed for Greece (3.065). The average LPI value of the members was calculated as 3.630. Nineteen OECD members had values higher than average, while the remaining 16 members had performance below average.

Figure 1: Average LPI of OECD Members

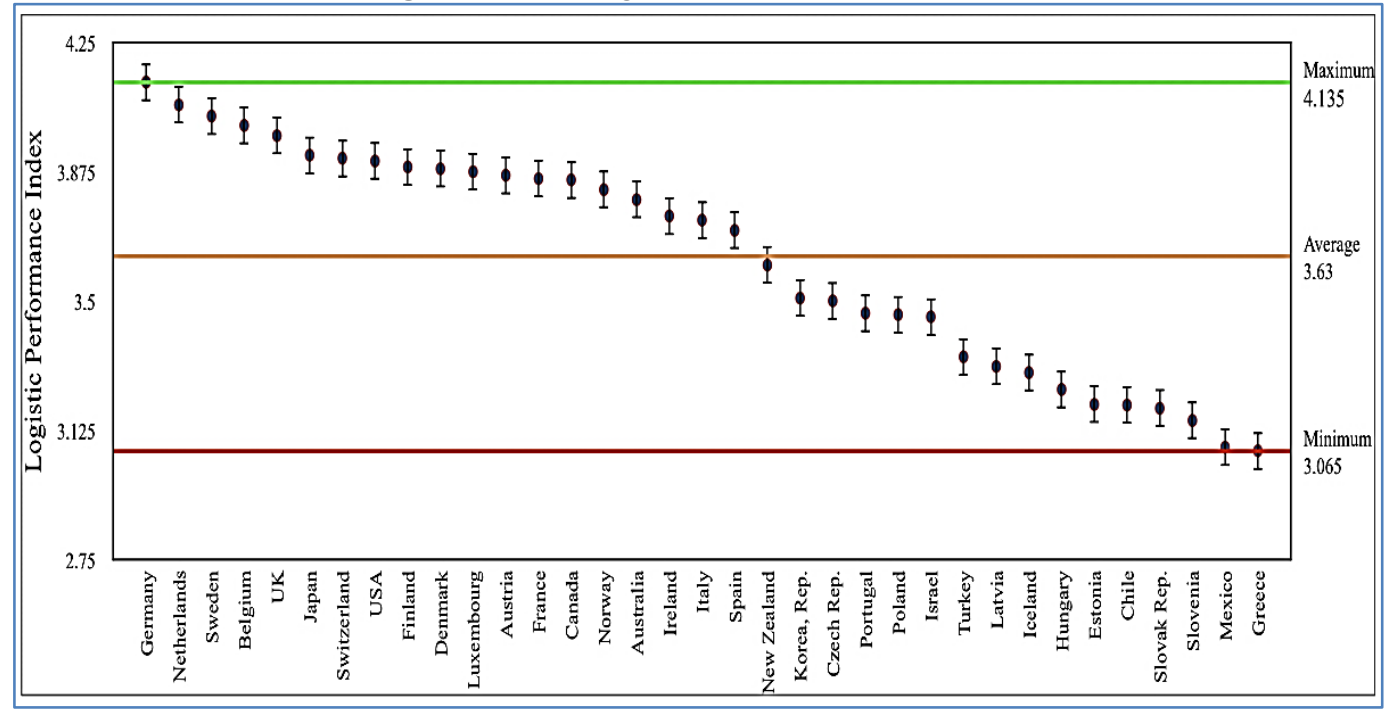

Three different types of equations, which had $3^{\text {rd }}, 4^{\text {th }}$, and exponential order, were formulated to calculate the LPI for the future depending on the degrees of reliability levels of these equations. Among the methods to be used in estimation studies, the most important one can be considered the degree of reliability or the minimum margin of error. The degree of reliability is defined as the degree to which stable and consistent results for the future are achieved due to a statistic analysis. The purpose of the equations derived is to minimize the distance of the data used from the plotted curve. In this way, the margin of error (or the standard error of the mean, standard deviation, variance) is minimized. Equations 
with high $\mathrm{R}^{2}$ values that give the minimum margin of error for each country were preferred. Every derived linear or nonlinear equation has a degree of reliability. However, after a certain degree, the values obtained from the equations' reliability degrees are fixed. In short, since linear, logarithmic, and power equations other than tertiary, quadratic, and exponential equations either have the same degree of reliability or have a smaller degree of reliability, no equations other than these three equations were created. For example, for Germany, the fourth-order equation is preferred as it has the highest $\mathrm{R}^{2}$ value. Fifth, sixth, seventh, etc. equations derived after the fourth-order were not considered because the equations for $\mathrm{R}^{2}$ are the same or have a lower $\mathrm{R}^{2}$ value. This situation is the same in other countries. Table 1 includes descriptive statistical data on LPI values as well as the type of equation used for each country.

Table 1: Types of Equations of OECD Members Relative to High $\mathrm{R}^{2}$

\begin{tabular}{|c|c|c|c|c|c|}
\hline Countries & Mean & SD & SS & Equation Type & R-Squared \\
\hline Australia & 3.7933 & 0.0458 & 86.3468 & $4^{\text {th }}$ order & 0.6528 \\
\hline Austria & 3.8650 & 0.1739 & 89.7807 & $4^{\text {th }}$ order & 0.6154 \\
\hline Belgium & 4.0083 & 0.0670 & 96.4229 & $4^{\text {th }}$ order & 0.9660 \\
\hline Canada & 3.8516 & 0.0658 & 89.0337 & $3^{\text {rd }}$ order & 0.7410 \\
\hline Chile & 3.1966 & 0.0954 & 61.3576 & Exponential & 0.9276 \\
\hline Czech Republic & 3.5000 & 0.1955 & 73.6912 & $4^{\text {th }}$ order & 0.8290 \\
\hline Denmark & 3.8850 & 0.0969 & 90.6063 & $4^{\text {th }}$ order & 0.6237 \\
\hline Estonia & 3.2000 & 0.1892 & 61.6190 & $3^{\text {rd }}$ order & 0.5468 \\
\hline Finland & 3.8900 & 0.1454 & 90.8984 & $3^{\text {rd }}$ order & 0.2837 \\
\hline France & 3.8533 & 0.0233 & 89.0918 & $4^{\text {th }}$ order & 0.8693 \\
\hline Germany & 4.1333 & 0.0717 & 102.532 & $4^{\text {th }}$ order & 0.9763 \\
\hline Greece & 3.0650 & 0.1699 & 56.5097 & $3^{\text {rd }}$ order & 0.7869 \\
\hline Hungary & 3.2433 & 0.2221 & 63.3620 & $3^{\text {rd }}$ order & 0.9551 \\
\hline Iceland & 3.2933 & 0.0930 & 65.1196 & $4^{\text {th }}$ order & 0.9525 \\
\hline Ireland & 3.7450 & 0.1819 & 84.3157 & $3^{\text {rd }}$ order & 0.5263 \\
\hline Israel & 3.4533 & 0.1739 & 71.7044 & $4^{\text {th }}$ order & 0.2211 \\
\hline Italy & 3.7333 & 0.1083 & 83.6854 & $4^{\text {th }}$ order & 0.6528 \\
\hline Japan & 3.9250 & 0.1165 & 92.5017 & $4^{\text {th }}$ order & 0.7275 \\
\hline Korea, Rep. & 3.5100 & 0.3595 & 74.5670 & $4^{\text {th }}$ order & 0.5596 \\
\hline Latvia & 3.3100 & 0.3242 & 66.2624 & $3^{\text {rd }}$ order & 0.7691 \\
\hline Luxembourg & 3.8750 & 0.2664 & 90.4487 & $4^{\text {th }}$ order & 0.8960 \\
\hline Mexico & 3.0750 & 0.0356 & 56.7401 & $3^{\text {rd }}$ order & 0.9000 \\
\hline Netherlands & 4.0700 & 0.0629 & 99.4092 & $4^{\text {th }}$ order & 0.9754 \\
\hline New Zealand & 3.6050 & 0.1796 & 78.1375 & $3^{\text {rd }}$ order & 0.5956 \\
\hline Norway & 3.8216 & 0.1310 & 87.7167 & $3^{\text {rd }}$ order & 0.4091 \\
\hline Poland & 3.4616 & 0.0444 & 71.9087 & $4^{\text {th }}$ order & 0.7742 \\
\hline Portugal & 3.4650 & 0.1225 & 72.1125 & $4^{\text {th }}$ order & 0.9840 \\
\hline Slovak Republic & 3.1883 & 0.1282 & 61.0751 & $4^{\text {th }}$ order & 0.8929 \\
\hline Slovenia & 3.1500 & 0.2261 & 59.7908 & $4^{\text {th }}$ order & 0.9993 \\
\hline Spain & 3.7066 & 0.0744 & 82.4640 & $3^{\text {rd }}$ order & 0.9362 \\
\hline Sweden & 4.0366 & 0.1194 & 97.8394 & $3^{\text {rd }}$ order & 0.9801 \\
\hline Switzerland & 3.9116 & 0.0783 & 91.8375 & $4^{\text {th }}$ order & 0.9932 \\
\hline Turkey & 3.3366 & 0.1585 & 66.9258 & $4^{\text {th }}$ order & 0.9568 \\
\hline United Kingdom & 3.9783 & 0.0587 & 94.9801 & $4^{\text {th }}$ order & 0.9330 \\
\hline United States & 3.9083 & 0.0495 & 91.6627 & $3^{\text {rd }}$ order & 0.8035 \\
\hline
\end{tabular}

SD: Standard deviation, $\mathbf{S S}$ : The sum of squares

According to one sample t-test statistical analysis, the confidence interval was estimated as $(0.6975 ; 0.8466)$. The standard deviation of the estimated value of LPI and standard error of the mean was calculated as 0.2169 and 0.0367 , which had very low levels. The maximum value of $\mathrm{R}^{2}$ belonging to Slovenia was calculated as 0.9993 , and the minimum $\mathrm{R}^{2}$ value regarding to Israel was found as 0.2211 (see Figure 2). 
Figure 2: The Values of $\mathrm{R}^{2}$

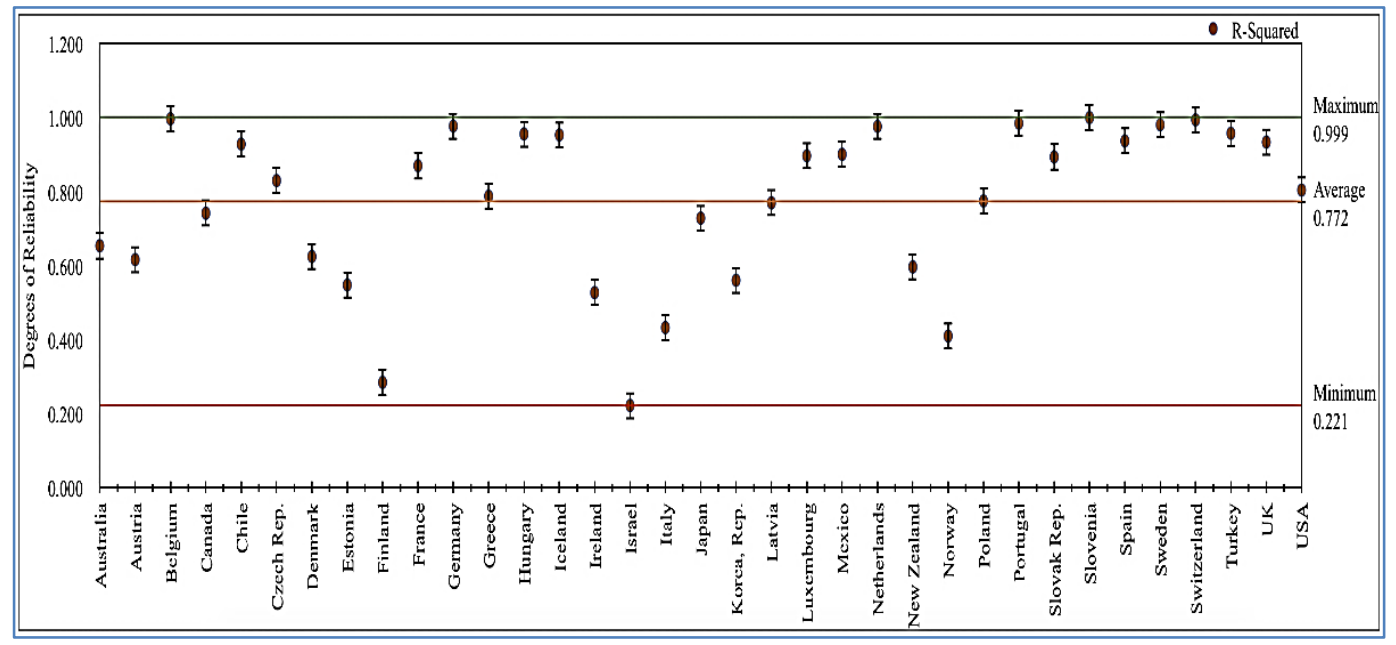

Thirty-five equations were constructed based on the degree of reliability for each member of the OECD. Two parameters were used in these equations. The variable of $y$ represents the LPI defined as the response variable for the future. The variable of $x$ symbolizes the subtraction of the next time value from the current time to calculate LPI of the members. All equations were defined as below for this study. below:

The $4^{\text {th }}$ order equation was formed with the 0.6528 degree of reliability for LPI of Australia as

$$
y=-0.0046 x^{4}+0.0603 x^{3}-0.26121 x^{2}+0.4102 x+3.64
$$
below:

The $4^{\text {th }}$ order equation was formed with the 0.6154 degree of reliability for LPI of Austria as

$$
y=-0.0148 x^{4}+0.02064 x^{3}-0.9634 x^{2}+1.7582 x+2.7583
$$
below:

The $4^{\text {th }}$ order equation was formed with the 0.9960 degree of reliability for LPI of Belgium as

$$
y=-0.0027 x^{4}+0.0293 x^{3}-0.0944 x^{2}+0.1222 x+3.885
$$
below:

The $3^{\text {rd }}$ order equation was formed with the 0.7410 degree of reliability for LPI of Canada as

$$
y=-0.0107 x^{3}+0.1013 x^{2}-0.2751 x+4.0667
$$
below:

The exponential equation was formed with the 0.9276 degree of reliability for LPI of Chile as

$$
y=3.028 e^{0.015 x}
$$
as below:

The $4^{\text {th }}$ order equation was formed with the 0.8290 degree of reliability for LPI of Czech Republic

$$
y=-0.0027 x^{4}+0.3025 x^{3}-1.3124 x^{2}+2.0924 x+2.4617
$$

The $4^{\text {th }}$ order equation was formed with the 0.6237 degree of reliability for LPI of Denmark as below:

$$
y=0.009 x^{4}-0.1081 x^{3}+0.4217 x^{2}-0.5926 x+4.1117
$$
below:

The $3^{\text {rd }}$ order equation was formed with the 0.5468 degree of reliability for LPI of Estonia as 


$$
y=-0.0242 x^{3}+0.2714 x^{2}-0.0 .8373 x+3.79
$$
below:

The $4^{\text {th }}$ order equation was formed with the 0.2837 degree of reliability for LPI of Finland as

$$
y=-0.0048 x^{4}+0.0848 x^{3}-0.4909 x^{2}+1.0553 x+3.2283
$$
below:

The $4^{\text {th }}$ order equation was formed with the 0.8693 degree of reliability for LPI of France as

$$
y=-0.0029 x^{4}+0.0369 x^{3}-0.1562 x^{2}+0.261 x+3.7
$$
below:

The $4^{\text {th }}$ order equation was formed with the 0.9763 degree of reliability for LPI of Germany as

$$
y=-0.0085 x^{4}+0.1126 x^{3}-0.486 x^{2}+0.7885 x+3.705
$$
below:

The $3^{\text {rd }}$ order equation was formed with the 0.7869 degree of reliability for LPI of Greece as

$$
y=-0.0207 x^{3}+0.2263 x^{2}-0.6486 x+3.4267
$$
below:

The $3^{\text {rd }}$ order equation was formed with the 0.9551 degree of reliability for LPI of Hungary as

$$
y=-0.0194 x^{3}+0.1873 x^{2}-0.3948 x+3.2067
$$
below:

The $4^{\text {th }}$ order equation was formed with the 0.9525 degree of reliability for LPI of Iceland as

$$
y=-0.0071 x^{4}+0.1075 x^{3}-0.5329 x^{2}+0.9354 x+3.7
$$
below:

The $3^{\text {rd }}$ order equation was formed with the 0.5263 degree of reliability for LPI of Ireland as

$$
y=-0.0241 x^{3}+0.2485 x^{2}-0.786 x+4.4967
$$

The $4^{\text {th }}$ order equation was formed with the 0.2211 degree of reliability for LPI of Israel as below:

$$
y=-0.0131 x^{4}+0.1781 x^{3}-0.8376 x^{2}+1.5926 x+2.4683
$$

The $4^{\text {th }}$ order equation was formed with the 0.6528 degree of reliability for LPI of Italy as below:

$$
y=0.0088 x^{4}-0.1168 x^{3}+0.506 x^{2}-0.7628 x+3.9933
$$

The $4^{\text {th }}$ order equation was formed with the 0.7275 degree of reliability for LPI of Japan as below:

$$
y=-0.0125 x^{4}+0.1700 x^{3}-0.7525 x^{2}+1.2036 x+3.3700
$$
below:

The $4^{\text {th }}$ order equation was formed with the 0.5596 degree of reliability for LPI of Korea, Rep. as

$$
y=-0.0402 x^{4}+0.5234 x^{3}-2.2122 x^{2}+3.3743 x+2.0283
$$

The $3^{\text {rd }}$ order equation was formed with the 0.7691 degree of reliability for LPI of Latvia as below:

$$
y=-0.0100 x^{3}+0.0129 x^{2}+0.2600 x+2.9400
$$
as below:

The $4^{\text {th }}$ order equation was formed with the 0.8960 degree of reliability for LPI of Luxembourg

$$
y=-0.0044 x^{4}+0.5655 x^{3}-2.4187 x^{2}+3.8765 x+2.0117
$$
below:

The $3^{\text {rd }}$ order equation was formed with the 0.9000 degree of reliability for LPI of Mexico as

$$
y=-0.0065 x^{3}+0.0606 x^{2}-0.1458 x+3.1433
$$



below:

The $4^{\text {th }}$ order equation was formed with the 0.9754 degree of reliability for LPI of Netherlands as

$$
y=-0.0115 x^{4}+0.1492 x^{3}-0.6484 x^{2}+1.0809 x+3.4983
$$
as below:

The $3^{\text {rd }}$ order equation was formed with the 0.5956 degree of reliability for LPI of New Zealand

$$
y=-0.0194 x^{3}+0.1609 x^{2}-0.3341 x+3.4533
$$
below:

The $3^{\text {rd }}$ order equation was formed with the 0.4091 degree of reliability for LPI of Norway as

$$
y=-0.0081 x^{3}+0.0833 x^{2}-0.2886 x+4.1600
$$

The $4^{\text {th }}$ order equation was formed with the 0.7742 degree of reliability for LPI of Poland as below:

$$
y=0.0044 x^{4}-0.0582 x^{3}+0.2660 x^{2}-0.4742 x+3.7050
$$
below:

The $4^{\text {th }}$ order equation was formed with the 0.9840 degree of reliability for LPI of Portugal as

$$
y=0.0177 x^{4}-0.2408 x^{3}+1.1049 x^{2}-1.9080 x+4.3683
$$
below:

The $4^{\text {th }}$ order equation was formed with the 0.8929 degree of reliability for LPI of Slovak Rep. as

$$
y=-0.0190 x^{4}+0.2411 x^{3}-1.0153 x^{2}+1.6075 x+2.4317
$$
below:

The $4^{\text {th }}$ order equation was formed with the 0.9993 degree of reliability for LPI of Slovenia as

$$
y=0.0285 x^{4}-0.4026 x^{3}+1.9035 x^{2}-3.3153 x+4.655
$$

The $3^{\text {rd }}$ order equation was formed with the 0.9362 degree of reliability for LPI of Spain as below:

$$
y=0.0020 x^{3}-0.0167 x^{2}+0.0698 x+3.5667
$$
below:

The $3^{\text {rd }}$ order equation was formed with the 0.9801 degree of reliability for LPI of Sweden as

$$
y=-0.0608 x^{3}+0.5682 x^{2}-1.531 x+5.108
$$
below:

The $4^{\text {th }}$ order equation was formed with the 0.9932 degree of reliability for LPI of Switzerland as

$$
y=-0.0152 x^{4}+0.2069 x^{3}-0.9366 x^{2}+1.5842 x+3.1317
$$
below:

The $4^{\text {th }}$ order equation was formed with the 0.9568 degree of reliability for LPI of Turkey as

$$
y=0.0098 x^{4}-0.1529 x^{3}+0.7690 x^{2}-1.3555 x+3.9450
$$

The $4^{\text {th }}$ order equation was formed with the 0.9330 degree of reliability for LPI of U.K. as below:

$$
y=-0.0063 x^{4}+0.0775 x^{3}-0.3112 x^{2}+0.4721 x+3.7200
$$

The $3^{\text {rd }}$ order equation was formed with the 0.8035 degree of reliability for LPI of USA as below:

$$
y=-0.0067 x^{3}+0.0611 x^{2}-0.1337 x+3.9400
$$

By comparing the equations based on $\mathrm{R}^{2}$, the type of equation where the $\mathrm{R}^{2}$ values of the countries were at the lowest level was expressed as the $4^{\text {th }}$ degree order equation which was constructed for Israel. On the contrary, the highest value of $\mathrm{R}^{2}$ belonged to the equation in $3^{\text {rd }}$ degree order for Slovenia. 


\section{RESULTS OF THE STUDY}

The methodology developed for this study has been used to calculate the estimated values of LPI that OECD members were expected to have in the future. The estimated values of LPI were obtained based on three different equation types. According to one sample t-test statistical analysis, the confidence interval was estimated as $(3.4803 ; 3.7413)$. The standard deviation of the estimated value of LPI and standard error of the mean were calculated as 0.3799 and 0.0642 , which had very low levels, respectively. The distribution of the data of estimated LPI was determined that was appropriate to the Johnson Transformation distribution. The data points followed a straight line, and the p-value of the data was determined as 0.207 , which was greater than 0.05 .

Figure 3: Future LPI of OECD Countries

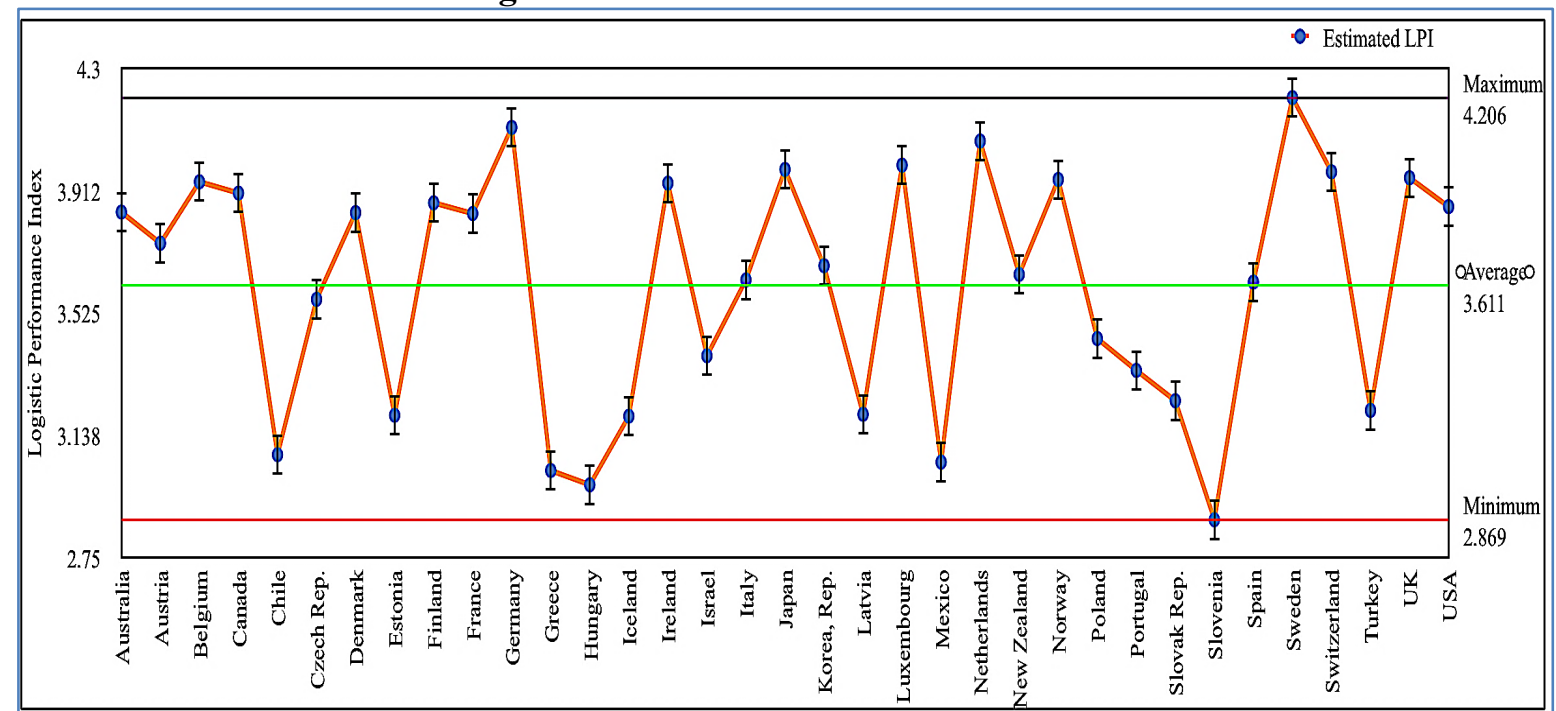

The estimated values of LPI for the members of the OECD were handled and examined one by one, depending on the created equations. The average value of LPI among all the calculated values of LPI was found as 3.611. The maximum value of LPI belonging to Sweden was calculated as 4.206, and the minimum value of LPI regarding to Slovenia was computed as 2.8690. The values of LPI for each member of OECD were depicted in Figure 3.

By comparing the equations, the type of equation where the LPI values of the countries were at the lowest level was expressed as the $4^{\text {th }}$ degree order equation which was constructed for Slovenia. Interestingly, this country had the highest value of $\mathrm{R}^{2}$. On the contrary, the highest value of LPI belonged to the equation with $3^{\text {rd }}$ degree order for Sweden.

Figure 4: The Average and Estimated Values of LPI

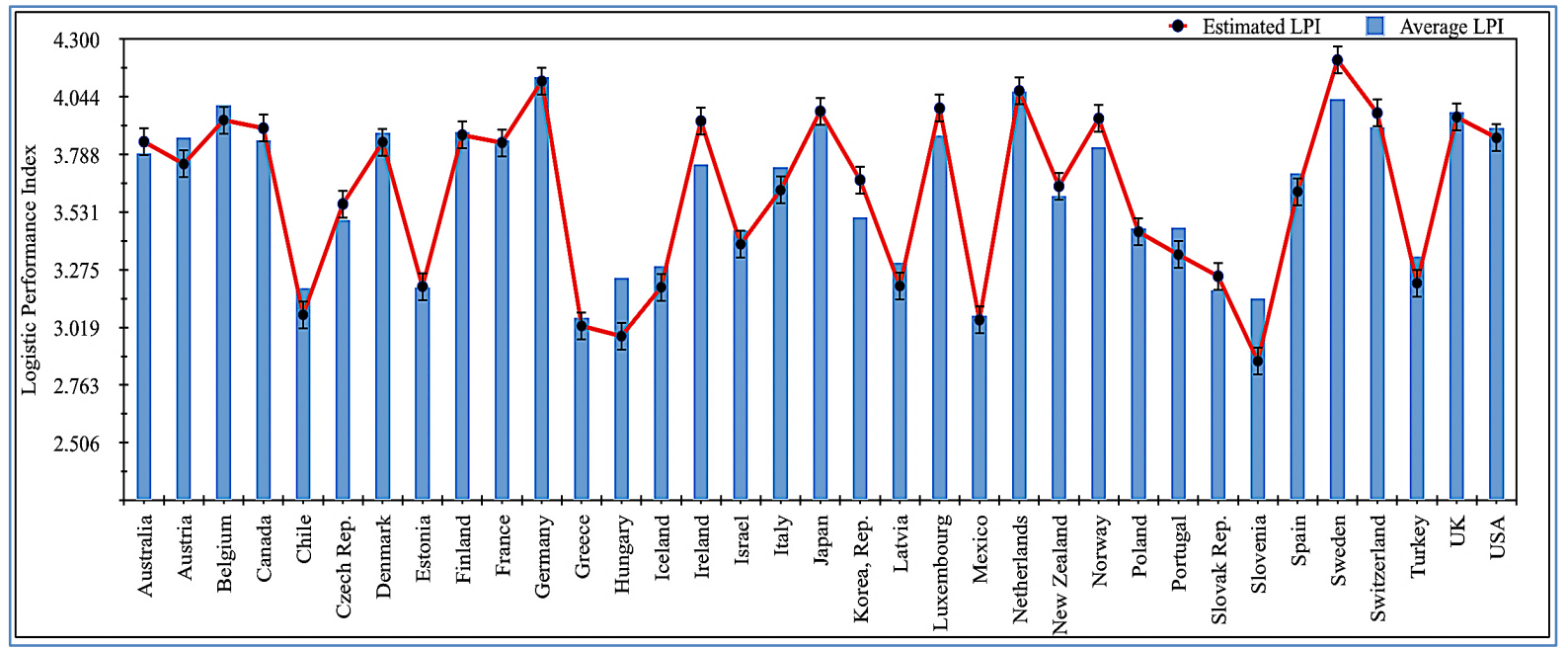


The behavior of equations shows directions of the lines for the estimated LPI. Likewise, the similarities are observed in the tendencies of power and logarithmic equations (See Hata! Başvuru kaynağı bulunamadı.).

As a result of the estimated LPI, we observed a decrease in the estimated LPI for the next period, especially in non-European countries. Chile, Iceland, Turkey, USA were illustrated as examples of this situation. We can emphasize that only 12 out of 36 countries' index values were higher than the average value of the LPI. Some values of LPI were observed that countries with high values of LPI had low values of LPI in previous years, such as Austria, Belgium, Hungary, Italy, etc. The reason for this situation should be examined in two parts as developed and developing countries. It can be interpreted that the values of LPI have decreased due to economic saturation or fluctuations in population rates in developed countries. Assuming that factors contribute positively to developing countries, the fact that they have interconnection routes (for example, Turkey; Asia to Europe, Mexico; South America to North America, vice versa), especially in product transportation, leads to high values of LPI. Since the data used do not exhibit continuity in time, it should be noted that the estimated LPI data was obtained for the next time, not for the following year. The comparison of the data can only be made when the World Bank obtained the LPI data generated for the next period. There were obvious differences between the estimated rank and pervious years rank in terms of OECD members (see Table 2).

Table 2: The Ranking of OECD Members Based on LPI

\begin{tabular}{|c|c|c|c|c|c|c|c|}
\hline \multirow{2}{*}{ Country } & \multicolumn{6}{|c|}{ Historical Data } & \multirow{2}{*}{$\begin{array}{r}\text { Estimated } \\
\text { Value }\end{array}$} \\
\hline & 2007 & 2010 & 2012 & 2014 & 2016 & 2018 & \\
\hline Australia & 16 & 16 & 15 & 14 & 16 & 15 & 14 \\
\hline Austria & 17 & 17 & 9 & 19 & 6 & 4 & 17 \\
\hline Belgium & 8 & 8 & 5 & 3 & 5 & 3 & 9 \\
\hline Canada & 12 & 12 & 12 & 11 & 11 & 17 & 11 \\
\hline Chile & 31 & 31 & 28 & 32 & 32 & 26 & 31 \\
\hline Czech Republic & 22 & 22 & 30 & 25 & 21 & 19 & 22 \\
\hline Denmark & 14 & 14 & 4 & 15 & 14 & 7 & 15 \\
\hline Estonia & 30 & 30 & 33 & 30 & 28 & 28 & 29 \\
\hline Finland & 11 & 11 & 1 & 21 & 12 & 9 & 12 \\
\hline France & 15 & 15 & 10 & 12 & 13 & 13 & 16 \\
\hline Germany & 1 & 1 & 2 & 1 & 1 & 1 & 2 \\
\hline Greece & 34 & 34 & 34 & 34 & 33 & 31 & 33 \\
\hline Hungary & 33 & 33 & 29 & 26 & 23 & 25 & 34 \\
\hline Iceland & 29 & 29 & 26 & 28 & 29 & 30 & 30 \\
\hline Ireland & 10 & 10 & 20 & 10 & 15 & 24 & 10 \\
\hline Israel & 24 & 24 & 19 & 31 & 22 & 29 & 24 \\
\hline Italy & 19 & 19 & 6 & 17 & 17 & 16 & 20 \\
\hline Japan & 6 & 6 & 17 & 9 & 10 & 5 & 5 \\
\hline Korea, Rep. & 20 & 20 & 35 & 18 & 20 & 22 & 18 \\
\hline Latvia & 26 & 26 & 13 & 27 & 31 & 35 & 28 \\
\hline Luxembourg & 4 & 4 & 23 & 7 & 2 & 21 & 4 \\
\hline Mexico & 32 & 32 & 31 & 35 & 35 & 33 & 32 \\
\hline Netherlands & 3 & 3 & 3 & 2 & 4 & 6 & 3 \\
\hline New Zealand & 18 & 18 & 25 & 20 & 27 & 12 & 19 \\
\hline Norway & 9 & 9 & 18 & 6 & 18 & 18 & 8 \\
\hline Poland & 23 & 23 & 24 & 24 & 24 & 23 & 23 \\
\hline Portugal & 25 & 25 & 22 & 22 & 26 & 20 & 25 \\
\hline Slovak Republic & 27 & 27 & 32 & 33 & 30 & 34 & 26 \\
\hline Slovenia & 35 & 35 & 27 & 29 & 34 & 27 & 35 \\
\hline Spain & 21 & 21 & 16 & 16 & 19 & 14 & 21 \\
\hline Sweden & 2 & 2 & 11 & 5 & 3 & 2 & 1 \\
\hline Switzerland & 5 & 5 & 14 & 13 & 9 & 10 & 6 \\
\hline Turkey & 28 & 28 & 21 & 23 & 25 & 32 & 27 \\
\hline United Kingdom & 7 & 7 & 8 & 4 & 7 & 8 & 7 \\
\hline United States & 13 & 13 & 7 & 8 & 8 & 11 & 13 \\
\hline
\end{tabular}

The ranking of Austria fell 17 spots based on the year 2018 and the estimated value of LPI dramatically. However, the estimated value of this member had the same ranking in the year of 2007 and 2010. Likewise, Belgium, Chile, Denmark, Hungary, New Zealand, Portugal, Slovenia, and Spain 
followed Austria in terms of ranking. The ranking of members, such as Iceland, Japan, and Poland were stable. Contrary, the ranking of 16 out of 35 members changed positively. The ranking of Ireland, Luxembourg, and Norway increased at most. As a result, a significant decrease in the estimated LPI values was observed in the majority of OECD members.

This study has some limitations. For example, reporting LPI values not continuously but in certain periods causes the data to conform to discrete data distribution. Another limitation is that the data are relatively short term. Nevertheless, we showed that an important study has emerged to deliver the following LPI values.

\section{CONCLUSION}

Logistics Performance Index (LPI) values of the countries were considered in order to show the development levels of the countries' logistics infrastructure. LPI is not only a value but also demonstrates the development of countries' trade infrastructure, such as customs procedures, logistics costs, land, sea, and air transport. LPI values are calculated by the World Bank. In this study, the LPI values of the next period were calculated by considering the previous and current LPI values of OECD members. The estimation series method was developed by using nonlinear equations for this study. The estimation data differed according to the degree of reliability of the equations. Estimated LPI data ranged from 2.869 to 4.206 , with an average value of 3.611 based on equations. According to the developed method of the study, the maximum value of LPI was estimated for Sweden. In contrast, the lowest value of LPI was determined for Slovenia among the members of OECD. As a result, a significant decrease in the estimated LPI values was observed for the majority of OECD members.

As a result of the study, we can emphasize that the high LPI value is relatively less related to the country population. The brand values of companies that provide more logistics support are high. It is not surprising that developed logistics systems exist in economically developing countries. The economic development of a country represents the development of the logistics industry. Thus, it ensures that countries with high LPI values have a strong competitive side in the logistics sector. The fact that there are few studies on LPI estimation (the first study on this subject) will be a very important resource for further studies.

\section{REFERENCES}

ARVIS, J. F., MUSTRA, M. A., OJALA, L., SHEPHERD, B. ve SASLAVSKY, D. (2010). Connecting to Compete 2010:Trade Logistics in the Global Economy-The Logistics Performance Index and Its Indicators. In The World Bank.

ARVIS, J. F., MUSTRA, M. A., OJALA, L., SHEPHERD, B. ve SASLAVSKY, D. (2012). Connecting to Compete 2012:Trade Logistics in the Global Economy-The Logistics Performance Index and Its Indicators.

ARVIS, J. F., OJALA, L., WIEDERER, C., SHEPHERD, B., RAJ, A., DAIRABAYEVA, K. ve KIISKI, T. (2018). Connecting to Compete 2018:Trade Logistics in the Global Economy-The Logistics Performance Index and Its Indicators. World Bank.

ARVIS, J. F., SASLAVSKY, D., OJALA, L., SHEPHERD, B., BUSCH, C. ve RAJ, A. (2014). Connecting to Compete 2014:Trade Logistics in the Global Economy-The Logistics Performance Index and Its Indicators. In The World Bank.

ARVIS, J. F., MUSTRA, M. A., PANZER, J., OJALA, L. ve NAULA, T. (2007). Connecting to Compete 2007:Trade Logistics in the Global Economy-The Logistics Performance Index and Its Indicators.

ARVIS, J. F., SASLAVSKY, D., OJALA, L., SHEPHERD, B., BUSCH, C., RAJ, A. ve NAULA, T. (2016). Connecting to Compete 2010:Trade Logistics in the Global Economy-The Logistics Performance Index and Its Indicators.

ATALAN, A. (2018). "Türkiye Sağlık Ekonomisi için İstatistiksel Çok Amaçlı Optimizasyon Modelinin Uygulanması". İşletme Ekonomi ve Yönetim Araştırmaları Dergisi, 1(1): 34-51. 
ATALAN, A. (2019). "The Impacts of Healthcare Resources on Services of Emergency Department: Discrete Event Simulation with Box-Behnken Design". Ponte International Scientific Researchs Journal, 75(6): 12-23.

ATALAN, A. (2020). "Forecasting for Healthcare Expenditure of Turkey Covering the Years of 20182050". Gümüşhane Üniversitesi Sağlik Bilimleri Dergisi, 9(1): 8-16. https://doi.org/10.37989/gumussagbil.538111

ATALAN, A., CINAR, Z. ve CINAR, M. (2020). "A Trendline Analysis for Healthcare Expenditure per Capita of OECD Members". Sigma Journal of Engineering and Natural Sciences, 10(3): 2335.

CHAPMAN, R. L., SOOSAY, C. ve KANDAMPULLY, J. (2003). "Innovation in Logistic Services and the New Business Model: A Conceptual Framework". International Journal of Physical Distribution \& Logistics Management, 33(7): 630-650.

CHILDERLEY, A. (1980). "The Importance of Logistics in the UK Economy". International Journal of Physical Distribution \& Mateials Management, 10(4): 185-192.

DAVIDSON, A. L. (2006). Key Performance Indicators in Humanitarian Logistics. Massachusetts Institute of Technology.

DEVKOTA, K. C., REGMI, A. D., POURGHASEMI, H. R., YOSHIDA, K., PRADHAN, B., RYU, I. C., DHITAL, M. R. ve ALTHUWAYNEE, O. F. (2013). "Landslide Susceptibility Mapping Using Certainty Factor, Index of Entropy and Logistic Regression Models in GIS and their Comparison at Mugling-Narayanghat Road Section in Nepal Himalaya". Natural Hazards, 65(1): 135-165.

HOLLWEG, C. ve WONG, M.-H. (2009). Measuring Regulatory Restrictions in Logistics Services. ERIA Discussion Paper Series, 14.

KARMARKAR, U. S. ve APTE, U. M. (2007). "Operations Management in the Information Economy: Information Products, Processes, and Chains". Journal of Operations Management, 25(2): 438453.

KOVÁCS, G. ve KOT, S. (2016). "New Logistics and Production Trends as the Effect of Global Economy Changes". Polish Journal of Management Studies, 14.

LAN, S. L. ve ZHONG, R. Y. (2018). "Coordinated Development Between Metropolitan Economy and Logistics for Sustainability". Resources, Conservation and Recycling, 128: 345-354.

LAN, S., YANG, C. ve HUANG, G. Q. (2017). "Data Analysis for Metropolitan Economic and Logistics Development". Advanced Engineering Informatics, 32: 66-76.

MARTÍ, L., PUERTAS, R. ve GARCÍA, L. (2014). The Importance of the Logistics Performance Index in International Trade. Applied Economics.

PUERTAS, R., MARTÍ, L. ve GARCÍA, L. (2014). "Logistics Performance and Export Competitiveness: European Experience". Empirica, 41(3): 467-480.

REZAEI, J., VAN ROEKEL, W. S. ve TAVASSZY, L. (2018). "Measuring the Relative Importance of the Logistics Performance Index Indicators using Best Worst Method". Transport Policy, 68: 158169.

THE WORLD BANK. (2018). The Lojistic Performance Index. https://lpi.worldbank.org/

TSENG, Y., YUE, W. L. ve TAYLOR, M. A. P. (2005). The Role of Transportation in Logistics Chain. 